\title{
Skin giant neoplastic ulcers - treatment options and clinical challenges
}

\author{
Siergiej Girnyi ${ }^{1}$, Katarzyna Serkies ${ }^{2}$, Radosław Jaworski ${ }^{3}$, Michał But ${ }^{4}$, Artur Wiski ${ }^{4}$, \\ Jolanta Komornicka ${ }^{5}$, Michał Pikuła ${ }^{6}$, Jacek Zieliński ${ }^{1}$ \\ ${ }^{1}$ Clinic of Oncological Surgery, Medical University of Gdańsk, Poland \\ 2Oncology and Radiation Therapy Clinic, Medical University of Gdańsk, Poland \\ ${ }^{3}$ Cardiac Surgery Clinic, Children's Memorial Health Institute, Warszawa, Poland \\ ${ }^{4}$ Voivodship Specialist Hospital, Koszalin, Poland \\ ${ }^{5}$ Department of Microbiology, University Clinical Center, Gdańsk, Poland \\ ${ }^{6}$ Laboratory of Tissue Engineering and Regenerative Medicine, Department of Embryology, Medical University of Gdańsk, Poland
}

Introduction. Skin giant neoplastic ulcers are a very serious diagnostic and therapeutic problem. The objective of this work was to present the experiences and strategies of our center concerning the treatment of this type of neoplastic ulcers. Material and methods. In this paper we present and analyze 15 cases of patients treated for giant ulcers. This represented $0.4 \%$ of all patients treated surgically for skin cancer in our center $(n=3983)$. Ulcers in this group of patients were located within the head $(n=6)$, chest $(n=4)$, abdomen $(n=2)$, male genitals $(n=1)$ and lower limbs $(n=2)$.

Results. Our observations indicate that the treatment of giant skin neoplastic ulcers (although they are relatively rare) is a major clinical challenge and requires individualized multidirectional diagnostic and therapeutic methods.

NOWOTWORY J Oncol 2019; 69, 1:12-17

Key words: skin ulcers, giant skin neoplastic ulcers, skin cancers

\section{Introduction}

Skin ulcers are a very serious diagnostic and therapeutic problem, which may affect different groups of oncological patients. These diseases are classified as chronic wounds. Ulcers can be one of the symptoms of cancer, including skin cancer, soft tissue cancer and cancer metastases. They can also appear as complications of radio- or chemotherapy. The most common neoplastic ulcers are skin cancers, including basal-cell carcinoma (BCC), squamous-cell carcinoma (SCC) and melanomas. Among metastatic neoplastic ulcers, the most frequently described are metastases of breast cancer and reproductive organ cancer [1-3]. In the medical literature, neoplastic ulcers are called skin giant neoplastic ulcers, large cancer ulcers, as well as major cancer ulcers [4-7]. For the purpose of this study, the definition of "giant neoplastic ulcers" was adopted, understood as chronic defects in body integuments (of neoplastic origin) that require:

- extensive local plastic surgery with the help of skin and fasciocutaneous flaps or

- the use of skin grafts of split thickness to cover the resulting loss of body integuments, or

- multiorgan or block resections.

It should be remembered that the surgeries of removing giant ulcers and supplementing the defects are associated with a high risk of complications. This is due to the need to perform extensive tissue resections and an increased risk of infection of the operated site due to the presence of multiple drug resistant bacterial flora.

The aim of this paper is to present the experiences of our center in the diagnostics and treatment of skin giant neoplastic ulcers and the applied therapeutic strategies. 


\section{Material and method}

In the years 2012-2018, 3983 patients with skin cancers ( $n=2885)$, melanoma $(n=726)$, sarcomas $(n=96)$ and single neoplastic metastases to body integuments $(n=276)$ were operated on in the Department of Oncological Surgery of the Medical University of Gdańsk (Tab. I). Among this group of patients in the CliniNet hospital IT system we were looking for patients who were treated due to giant neoplastic ulcers. We adopted the following search criteria:

- diagnosis of: skin cancers (C44.0-C44.7 according to ICD 10), melanomas (C43-C43.8 according to ICD 10), sarcomas (C49-C49.9 according to ICD 10) and metastases of other skin cancers (C76-C76.8 according to ICD 10),

- procedures: radical excision of the skin lesion (86.4 ICD 9), stitching skin and subcutaneous tissue (86.5 according to ICD 9), free skin grafting (86.6 according to ICD 9), pedicled or free skin flap (86.7 according to ICD 9).

Based on the search results, 15 patients ( $0.4 \%$ of patients treated surgically with skin cancers) aged 20-80 years, in whom giant neoplastic ulcers were found, were qualified for further analysis. We excluded from the study patients with features of cancer spread and those who did not consent to surgical treatment. We obtained the consent of the local bioethics commission (KBN/180/2012) to conduct the study, and the patients qualified for this analysis gave their conscious written consent to participate in the study.

Each patient qualified for the study was treated according to one diagnostic and therapeutic scheme in accordance with the guidelines of oncological treatment. The panel of experts qualifying for surgery and further oncological treatment included specialists in oncological, plastic and urological surgery, laryngology, clinical oncology and radiotherapy. In the preoperative period, patients were examined in detail physically, computed tomography, chest radiography were performed and biological material for microbiological evaluation (tissue sample from the ulcer margins) was collected. The advancement of the cancer process was assessed according to the TNM classification ( $8^{\text {th }}$ edition) [8]. On the day preceding the surgery, ulcer swabs were taken for microbiological examination. Before the surgery, the planned surgical incision lines were marked, taking into account the extent of preparation of skin flaps and ulcer location. After ulcer resection within macroscopically healthy tissues, local reconstruction of the defect with the use of skin and fasciocutaneous flaps and skin grafts was started.
During difficult reconstructions, procedures in the team were performed with the participation of a plastic surgeon, urologist and laryngologist. In the analysis of patients operated on because of giant skin ulcers, we took into account the location of an ulcer, postoperative pathomorphological result, the extent of resection and complications. In addition, we analyzed selected parameters from the postoperative period, such as the duration of the procedure and the length of hospital stay.

\section{Results}

The analysis of wound healing showed a proper healing by rapid growth in 14 patients. Only in 1 patient the presence of necrosis covering about 30\% of grafted skin surface healed by granulation was observed. For the whole group of patients the surgery duration time was 60-120 minutes, and the average hospital stay was 10 days (4-28 days).

\section{Skin cancers}

Detailed demographic and clinical characteristics of patients with ulcerated skin cancer are presented in Table II $(n=10)$. The average age of patients was 72 years (range: 48-91 years). Ulcers in this group of patients were located within the head $(n=5)$, chest $(n=3)$, abdomen $(n=1)$ and male genitals $(n=1)$. In histopathological evaluation only squamous-cell carcinomas $(n=10)$ were diagnosed with $G 1(n=1), G 2(n=7)$ and $G 3$ $(n=2)$ malignancy.

\section{Skin melanomas}

In the analyzed group of patients with giant neoplastic ulcers, two female patients with skin melanomas were described. The first one of them (at the age of 67) had a cheek ulcer. The cancer spread was excluded and the patient was qualified for resection of the lesion together with evaluation of the sentinel node. The ulcer was excised and the local skin plastic surgery was performed. In histopathological evaluation nodular melanoma exulcerans (18 mm Breslow, Clark level V, mitotic index $11 / \mathrm{mm}^{2}$ ) was described. Finally, the stage of tumor progression was described as pT4bN1(sn)MO. Due to the presence of macroprojection in the guard node, cervical lymphadenectomy was performed in the lateral triangle of the neck.

The second patient (76 years old) was diagnosed with ulcerated melanoma located on her back. The ulcer was excised and local plastic surgery was performed with the use of fasciocutaneous flaps. In histopathological evaluation nodular

Table I. Patients with skin giant neoplastic ulcers treated in the years 2012-2018 in the Clinic of Oncological Surgery of the Medical University of Gdańsk

\begin{tabular}{|c|c|c|}
\hline Type of neoplasm & Number of patients $(n=3983)$ & Patients with skin giant neoplastic ulcers $(n=15)$ \\
\hline Skin cancer & 2885 & $10(0.35 \%)$ \\
\hline Melanoma & 726 & $2(0.3 \%)$ \\
\hline Sarcoma & 96 & $2(2.1 \%)$ \\
\hline Cancer metastasis* & 276 & $1(0.36 \%)$ \\
\hline
\end{tabular}

* renal cancer metastasis 
Table II. Detailed demographic and clinical characteristics of patients with ulcerated skin cancer treated in the years 2012-2018 in the Clinic of Oncological Surgery, Medical University of Gdańsk

\begin{tabular}{|c|c|c|c|c|c|c|c|c|}
\hline Item & Sex & Age & Location & Microscopic type & $\begin{array}{l}\text { Participation } \\
\text { of specialists }\end{array}$ & Excision range & $\begin{array}{l}\text { Type of plastic } \\
\text { surgery }\end{array}$ & Complications \\
\hline 1 & M & 56 & $\begin{array}{l}\text { External genital } \\
\text { organs }\end{array}$ & $\begin{array}{l}\text { Skin cancer, } \\
\text { invasive, G2 }\end{array}$ & $\begin{array}{l}\text { Oncological } \\
\text { surgeon, } \\
\text { urologist }\end{array}$ & Male genital excision & $\begin{array}{l}\text { Urethral plastic } \\
\text { surgery } \\
\text { Split thickness free } \\
\text { skin graft }\end{array}$ & Not observed \\
\hline 2 & M & 79 & Cheek & $\begin{array}{l}\text { Skin cancer, } \\
\text { invasive, G2 }\end{array}$ & $\begin{array}{l}\text { Oncological } \\
\text { surgeon, } \\
\text { laryngologist }\end{array}$ & $\begin{array}{l}\text { Parotid gland } \\
\text { excision with } \\
\text { superficial } \\
\text { lobe; cervical } \\
\text { lymphadenectomy** }\end{array}$ & $\begin{array}{l}\text { Local plastic } \\
\text { surgery with skin } \\
\text { flaps }\end{array}$ & Not observed \\
\hline 3 & M & 48 & Chest & $\begin{array}{l}\text { Skin cancer, } \\
\text { invasive, G2 }\end{array}$ & $\begin{array}{l}\text { Oncological } \\
\text { surgeon }\end{array}$ & Excision & $\begin{array}{l}\text { Split thickness skin } \\
\text { graft }\end{array}$ & $\begin{array}{l}\text { Partial necrosis } \\
\text { of a graft with } \\
\text { healing by } \\
\text { granulation }\end{array}$ \\
\hline 4 & M & 79 & $\begin{array}{l}\text { Hairy skin of the } \\
\text { head }\end{array}$ & $\begin{array}{l}\text { Skin cancer, } \\
\text { invasive, G3 }\end{array}$ & $\begin{array}{l}\text { Oncological } \\
\text { surgeon, plastic } \\
\text { surgeon }\end{array}$ & $\begin{array}{c}\text { Excision, local plastic } \\
\text { surgery }\end{array}$ & $\begin{array}{l}\text { Resection of one } \\
\text { of the edges of } \\
\text { the scar }\end{array}$ & Not observed \\
\hline 5 & $\mathrm{~F}$ & 71 & $\begin{array}{l}\text { Hairy skin of the } \\
\text { head }\end{array}$ & $\begin{array}{l}\text { Skin cancer, } \\
\text { invasive, G21 }\end{array}$ & $\begin{array}{l}\text { Oncological } \\
\text { surgeon }\end{array}$ & Excision & $\begin{array}{l}\text { Local plastic } \\
\text { surgery }\end{array}$ & Not observed \\
\hline 6 & M & 85 & Abdomen & $\begin{array}{l}\text { Skin cancer, } \\
\text { invasive, G2 }\end{array}$ & $\begin{array}{l}\text { Oncological } \\
\text { surgeon }\end{array}$ & Excision & $\begin{array}{l}\text { Local plastic } \\
\text { surgery }\end{array}$ & Not observed \\
\hline 7 & $\mathrm{~F}$ & 91 & Temple & $\begin{array}{l}\text { Skin cancer, } \\
\text { invasive, G2 }\end{array}$ & $\begin{array}{l}\text { Oncological } \\
\text { surgeon }\end{array}$ & Excision & $\begin{array}{l}\text { Local plastic } \\
\text { surgery }\end{array}$ & Not observed \\
\hline 8 & M & 71 & Back & $\begin{array}{l}\text { Skin cancer, } \\
\text { invasive, G2 }\end{array}$ & $\begin{array}{l}\text { Oncological } \\
\text { surgeon }\end{array}$ & Excision & $\begin{array}{l}\text { Local plastic } \\
\text { surgery }\end{array}$ & Not observed \\
\hline 9 & M & 67 & $\begin{array}{l}\text { Hairless skin of the } \\
\text { head }\end{array}$ & $\begin{array}{l}\text { Skin cancer, } \\
\text { invasive, G21 }\end{array}$ & $\begin{array}{l}\text { Oncological } \\
\text { surgeon, plastic } \\
\text { surgeon }\end{array}$ & Excision & $\begin{array}{l}\text { Local plastic } \\
\text { surgery }\end{array}$ & Not observed \\
\hline 10 & M & 70 & Chest & $\begin{array}{l}\text { Skin cancer, } \\
\text { invasive, G2 }\end{array}$ & $\begin{array}{l}\text { Oncological } \\
\text { surgeon }\end{array}$ & Excision & $\begin{array}{l}\text { Split thickness skin } \\
\text { graft }\end{array}$ & Not observed \\
\hline
\end{tabular}

melanoma exulcerans was diagnosed (13.5 mm Breslow, Clark level $\mathrm{V}$, mitotic index $15 / \mathrm{mm}^{2}$ ). No metastases were found in the excised sentinel node marked with dye-isotope method from the left armpit. The stage of tumor progression was described as PT4bNOMO.

\section{Sarcomas}

In the analyzed clinical material 2 patients with giant ulcerated sarcomas were described. In the first of them (at the age of 92) the extensive ulcer was located on the medial surface of the left thigh. The ulcer was excised and local skin plastic surgery was performed with the use of fasciocutaneous flaps. In histopathological report undifferentiated pleomorphic sarcoma (high grade pT4NxMx) was described and R0 resection was achieved. In the second patient (aged 88 years) ulcerated tumor of the left knee was found. After the tumor resection, the histopathological examination described undifferentiated pleomorphic sarcoma and R0 resection was achieved.

\section{Single metastasis of kidney cancer to the skin}

An isolated metastasis of kidney cancer to the skin was found in one patient - a 73-year-old male whose kidney had been removed 22 years earlier due to cancer. In our center, the patient underwent surgery to remove a metastatic tumor to the skin located in the central part of the abdomen. The histopathological evaluation of excised skin ulcer confirmed the diagnosis of metastasis of clear-cell carcinoma of the kidney with $\mathrm{RO}$ resection.

With respect to the whole group, postoperative analysis of the results of pathomorphological examinations showed that in 14 patients radical resection (RO) was achieved. With only one person (with skin cancer) R1 resection was achieved. In the last case, the resection was performed again and full oncological radicalization was achieved.

In microbiological evaluation of ulcers, Gram-positive bacteria dominated among isolated bacteria, such as Staphylococcus aureus, Staphylococcus epidermidis, Enterococus faecalis and streptococci, whereas among Gram-negative bacteria Escherichia coli, Pseudomonas spp. as well as Proteus mirabilis and Serratia marcensensens were found.

\section{Discussion}

Giant neoplastic ulcers are a serious challenge for modern oncological surgery. In cancer patients, these are the most 
common symptoms of a significant advancement of the disease. In our material, giant skin ulcers occurred in about $0.4 \%$ of patients treated surgically for skin cancer. In the analyzed clinical material, extensive neoplastic ulcers occurred most frequently in patients with skin cancer, which corresponds to the literature data [4]. Therapeutic decisions were made within the framework of the panel of experts, which included specialists in various fields of surgical and conservative medicine. The procedures were performed by oncological surgeons and doctors of other specialties, including plastic surgeons, laryngologists and urologists.

The type of cancer plays an important role in the preoperative evaluation of patients with skin cancer. In patients with skin cancer, the local and regional lymph node status should be assessed first. In melanomas, sarcomas and ulcerated metastases of other cancers, the presence of multiple metastases and spreading features of the disease (computed tomography, magnetic resonance imaging or PET) should be excluded in the first place [5]. The most important objective of surgical treatment of skin giant neoplastic ulcers is radical excision of the tumor. Therefore, in the preoperative diagnostics it is important to determine the stage of cancer advancement.

In our center, skin giant neoplastic ulcers in patients suffering from skin cancer were most often located in the area of the head (including the face), then on the torso, and rarely on the external genital organs. These results also correspond to the literature data [4]. It was particularly difficult to operate on perineal ulcers, where in the patient - apart from extensive tissue defect after resection - it was necessary to perform an external genital amputation and local urethral plastic surgery. A difficult clinical case was also the removal of the ulcer of the cheek area with the infiltration of the superficial lobe of the parotid gland, where branches of the facial nerve had to be spared with special attention.
It should be emphasized that in patients with giant neoplastic ulcers it is necessary to perform a radical $\mathrm{RO}$ resection and in case of $\mathrm{R} 1$ resection the surgery should be considered.

Healing of postoperative wounds in the observed patients was carried out by rapid growth, however, in one patient partial necrosis of a dermal graft was observed, which prolonged the period of full wound healing to several weeks.

\section{Surgical technique}

Apart from proper qualification for surgery, surgical technique and experience of the team are important in the case of extensive neoplastic ulcers. One of the factors influencing difficult healing of the postoperative wound may be the local infection, which often accompanies ulcers. We used our own technique to isolate an ulcer from the rest of the surgical field using a surgical napkin soaked in disinfectant and placed on the ulcer. After isolating the ulcer, we disinfected the surgical field again. In order to achieve a good therapeutic effect, it is extremely important to plan surgical cuts in order to be able to perform a plastic surgery of the wound with skin and fasciocutaneous flaps or to perform split thickness skin graft (Figs. 1 and 2).

\section{Bacterial colonization of neoplastic ulcers}

Neoplastic ulcers are chronic wounds often colonized or infected with various microorganisms, which also makes surgical treatment difficult and may cause postoperative complications. There are favorable conditions for bacterial growth in cancer tissue: low oxygen concentration allows the growth of both anaerobic and aerobic bacteria. Intensified local angiogenesis leads to the formation of a network of small blood vessels with endothelial defects, through which microorganisms spread in the tissue [9]. Disturbances of local immune response associated with the presence of cancer allow for uncontrolled
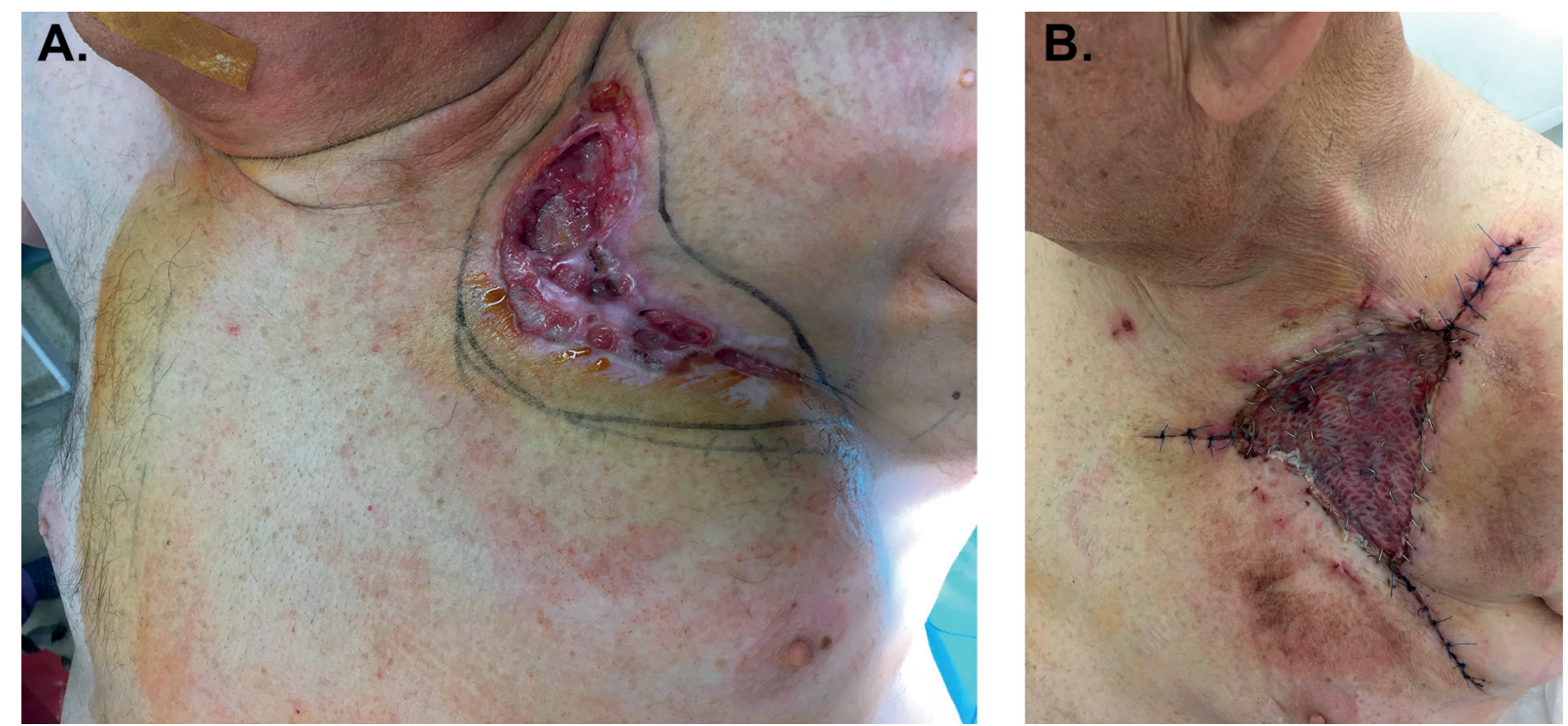

Figure 1. A giant neoplastic ulcer near the area of the left shoulder (a). Condition after excision and restoration of the left shoulder cavity with local plastic surgery of the grafted skin (b) 

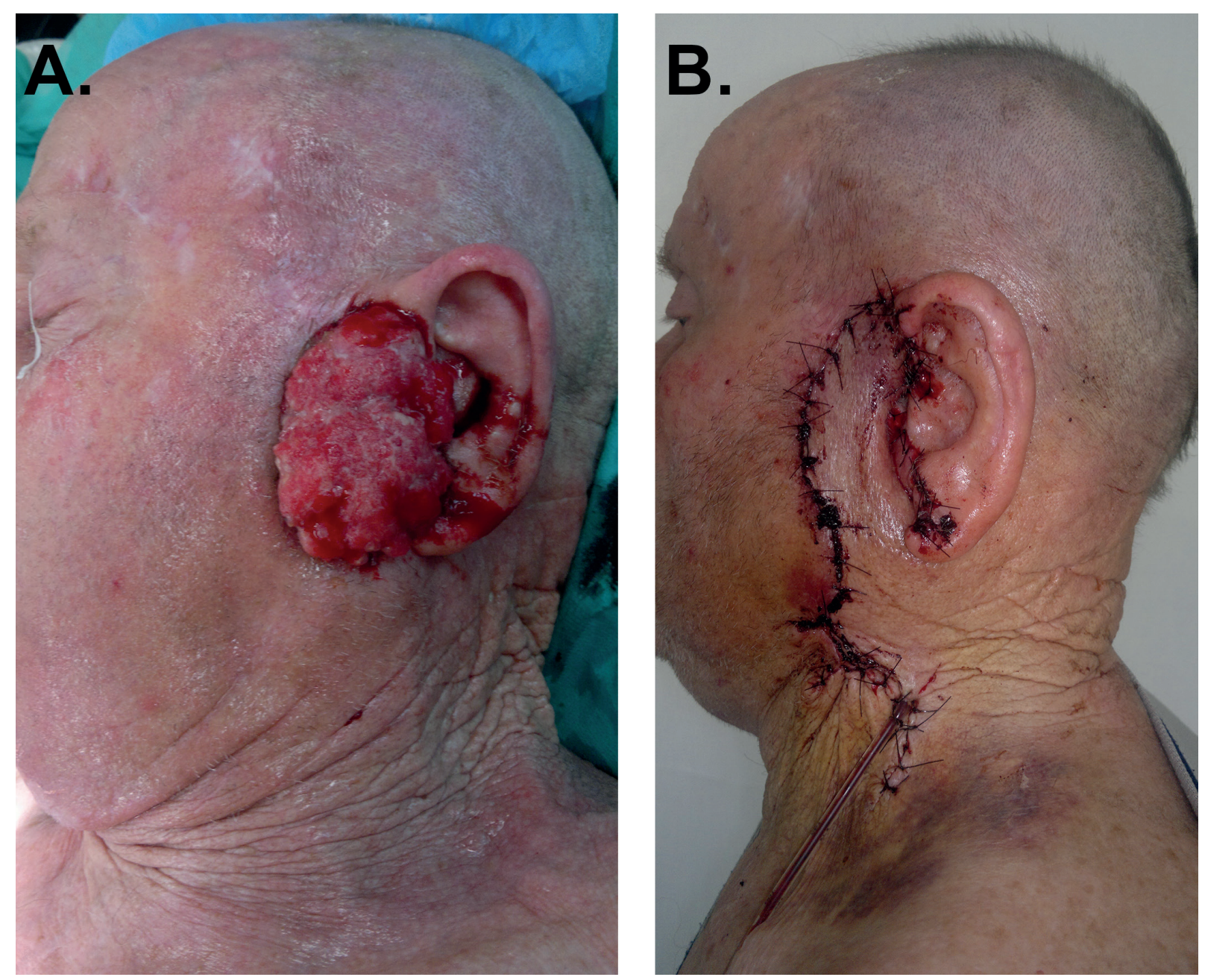

Figure 2. A giant skin cancer with infiltration of the parotid gland (a). Postoperative condition with removal of the tumor with parotid gland and lymphedenectomy of the lateral triangle of the neck (b)

proliferation of microorganisms. Proliferating bacteria also secrete pro-inflammatory factors, cytokines and chemokines, which may contribute to cancer progression [10]. Neoplastic ulcers are usually covered with necrotic tissues that contain nutrients used by bacteria.

The microflora of neoplastic ulcers is also dependent on the area of the lesion in which the neoplasm is located - ulcers of the neck and head are more often colonized by Gram-positive bacteria (e.g. Streptococcus spp.) and anaerobes from the upper respiratory tract flora, whereas the area of the abdomen, rectum and genitourinary tract is dominated by Gram-negative bacteria (most often Klebsiella spp, Escherichia coli, Proteus spp., Pseudomonas aeruginosa) and also enterococci. Ulcers associated with skin cancers are often colonized or infected with Staphylococcus aureus. It should be noted, however, that the presence of bacteria in a cancer ulcer does not always indicate infection. It is often a massive colonization, which does not require antibiotic therapy.

In the case of the planned repair operation of large ulcers, microbiological diagnostics (cultures from the border of healthy tissues after the removal of superficial necrosis) is sug- gested. Knowledge of the bacterial flora of ulceration may facilitate the initiation of appropriate antibiotic therapy in case of postoperative infection [11].

\section{Prospects for the treatment of giant skin neoplastic ulcers}

Progress in tissue engineering and regenerative medicine offer more and more possibilities for the reconstruction of defects caused by surgical skin removal. Hypothetical possibilities include the use of biomaterials as well as materials combined with various types of cells. Attempts are being made to use fibrin gels, collagen gels and other materials of high biocompatibility and clinical safety. The materials are intended to provide temporary wound cover and promote the natural processes of tissue regeneration and reconstruction. This can be done by stimulating the migration and proliferation of skin cells (keratinocytes, fibroblasts), adipose stem cells and other cells residing in the skin and subcutaneous tissue. These materials may also have an immunomodulatory effect, which may stimulate tissue regeneration, e.g. by polarization of macrophages (M1/M2) or anti-inflammatory effects. A number of scientific and clinical 
studies on new biomaterials and therapies are currently being conducted around the world in order to achieve even greater efficiency and safety in the treatment of skin defects [12-14].

\section{Conclusions}

Giant skin ulcers occur mostly in the course of skin cancers, and are rarely caused by the metastasis of other cancers to the skin. Multidirectional activities with the participation of doctors of various specialties may be the basis for effective treatment of extensive ulcerations. Tissue engineering creates new opportunities for the treatment of giant ulcers and tissue defects, which in the future may be a chance for patients in whom conventional methods of treatment do not have the appropriate clinical effect.

\section{Conflict of interest: none declared}

\section{Jacek Zieliński}

Medical University of Gdańsk

Clinic of Oncological Surgery

ul. Smoluchowskiego 17

80-214 Gdańsk, Poland

e-mail:jaziel@gumed.edu.pl

Received: 8 Feb 2019

Approved for printing: 27 Mar 2019

\section{References}

1. Seman S. Management of malignant fungating wound in advanced cancer. Semin Oncol Nurs 2006; 22: 185-193.

2. Sopata M, Ciupińska M, Głowacka A et al. Effect of octenisept antiseptic on bioburden of neoplastic ulcers in patients with advances cancer. J Wound Care 2008; 17: 24-27.

3. Sopata M, Tomaszewska E, Muszyński Z et al. The pilot study assessing efficacy and versatility of novel therapy for neoplastic ulceration: clinical and microbiological aspects. Postep Derm Alergol 2013; 4: 237-245.

4. Ricotti C, Bouzari N, Agadi A. Malignant skin neoplasms. Med Clin N Am 2009; 93: 1241-1264.

5. Meaume S, Fromantin I, Teot L. Neoplastic wounds and degenerescence. J. Tissue Viability 2013; 22: 122-130.

6. Palubicka A, Wekwejt M, Swieczko-Zurek B et al. Powikłania po rekonstrukcji piersi: problem zakażeń i strategii prewencyjnej - przegląd literaturowy. Chirurgia plastyczna i oparzenia 2017; 5: 89-97.

7. Deptuła M, Zieliński J, Wardowska A et al. Wound healing complications in oncological patients: perspectives for cellular therapy. Adv Dermatol Alergol 2019; XXXVI: 139-146.

8. Sobin LH, Wittekind C: TNM Classifiation of malignant tumours, ed. 8 New Jersey, 2017.

9. Baban CK. Bacteria as vectors for gene therapy of cancer. Bioeng Bugs 2010; 1: 385-394.

10. Grivennikov SI, Wang K, Mucida D et al. Adenoma-linked barrier defects and microbial products drive IL-23/IL-17-mediated tumour growth. Nature 2012; 491: 254-258.

11. Mager DL. Bacteria and cancer: cause, coincidence or cure? A review. J Transl Med 2006; 4: 14

12. Schumacher A, Cichorek M, Pikuła M. Komórki macierzyste tkanki tłuszczowej w inżynierii tkankowej i terapii trudno gojących się ran. Postepy Hig i Med Dośw 2018; 72: 806-821.

13. Mieczkowska A, Schumacher A, Filipowicz $\mathrm{N}$ et al. Immunophenotyping and transcriptional profiling of in vitro cultured human adipose tissue derived stem cells. Sci Rep 2018; 27: 11339.

14. Savoji H, Godau B, Hassani MS et al. Skin tissue substitutes and biomaterial risk assessment and testing. Front Bioeng Biotechnol 2018; 6: 86. 